\title{
Full-bridge Modular Multilevel Converter (FB-MMC) with Extended Control Range
}

\author{
Grain Philip Adam ${ }^{1}$, Stephen Finney ${ }^{1}$, Barry Williams ${ }^{1}$, Innocent Ewean Davidson ${ }^{2}$ and Abdelaziz Yousif Mohammed Abbas ${ }^{3}$ \\ ${ }^{1}$ Electronic and Electrical Engineering Department \\ University of Strathclyde ${ }^{1}$ \\ Glasgow, UK \\ grain.adam@strath.ac.uk \\ ${ }^{2}$ Eskom Centre of Excellence in HVDC \\ Engineering, School of Engineering \\ University of KwaZulu-Natal, S. Africa \\ Davidson@ukzn.ac.za \\ ${ }^{3}$ School of Electrical and Nuclear \\ Engineering \\ Sudan University, Sudan \\ abdelazizyousif@sustech.edu
}

\begin{abstract}
This paper presents an attractive control scheme that decouples cell capacitor voltage regulation of the FBMMC from the dc link voltage regulation. This is achieved by manipulating both ac and dc components of modulation functions. The dc component of modulation function is used to regulate the cell capacitor voltages independent of the dc link voltage, while the magnitude and phase of modulation function ac component are manipulated to control active and reactive powers FB-MMC exchanges with the ac grid. The significance of this control scheme is that it permits the FBMMC to operate with variable dc link voltage, including negative dc link voltage and zero, while full control over the power FB-MMC exchanges with ac grid is retained. Additionally, this paper provides comprehensive discussion of MMC fundamental theory, including logical and mathematical derivations of the basic relationships that governed its operation and modulation. The validity of the presented control scheme is confirmed using simulations.
\end{abstract}

Key words-Half and full-bridge modular multilevel converters; hybrid multilevel converters; high-voltage DC transmission systems; and multi-terminal HVDC networks.

\section{INTRODUCTION}

As many countries are expected to adopt large-scale offshore wind farms to reduce their $\mathrm{CO} 2$ and greenhouse gases emission, several voltage source converter high-voltage dc (VSC-HVDC) transmission systems will be built to transmit these powers to the consumption centers. Recent evolution of smart grids and development of multi-terminal HVDC networks may require new types of voltage source converters, which are efficient and resilient to ac and dc network faults. Some of the existing converter topologies with potential to meet some of these requirements are half and full bridge MMCs, and a number of hybrid converters recently proposed [1-19]. Some of the attractive hybrid multilevel converters for multi-terminal HVDC networks that can match the performance of half and full-bridge MMC during dc network faults with minimal impact on the ac side voltage are: mixed cells MMC, alternative arm MMC and hybrid cascaded converters [8, 9, 12, 20-24]. However, mixed cell MMC offers dc fault blocking with lower semiconductor losses than the FB-MMC and inherent all the attributes of FB-MMC [2531]. This paper exploits the control scheme recently presented in[32] to explore the increased operational possibilities the FB-MMC can offer when used in HVDC links. The significance of this contribution is that it allows cell capacitor voltage regulation to be decoupled from dc link voltage; thus, enables the HVDC link to exchange active and reactive powers independent of dc link voltage. Although will not be demonstrated in this paper, the control scheme Figure 2 can facilitate VSC-HVDC link to be operated with positive and negative dc link as conventional line commutating current source converter HVDC links. This paper uses simulation results obtained from two-terminal symmetrical monopole HVDC link that employs 21-cell FB-MMC to demonstrate the viability of the presented control scheme. The presented simulation results show that the proposed control scheme makes HVDC links that employ FB-MMC to be superior than all other types of VSC systems that can work harmoniously beside LCC-HVDC link in generic dc grid.

\section{Fundamental Theory OF Modular Multilevel CONVERTER}

Figure 1 (c) shows a linear model of the phase leg of the fullbridge modular multilevel converter (FB-MMC) in Figure 1(a). This simplified model is used to illustrate the fundamental theory of the MMC and its control strategy. Using Kirchhoff's current and voltage laws, algebraic and differential equations that describe MMC steady state and internal dynamics in open loop (set $v_{g}=0$, when $\mathrm{MMC}$ is connected to passive load)are:

$$
\begin{aligned}
& i_{o}=i_{1}-i_{2} \\
& \frac{1}{2} V_{d c}-v_{1}-v_{o}=R_{a} i_{1}+L_{a} \frac{d i_{1}}{d t} \\
& \frac{1}{2} V_{d c}-v_{2}+v_{o}=R_{a} i_{2}+L_{a} \frac{d i_{2}}{d t}
\end{aligned}
$$

Where $i_{1}$ and $i_{2}$ are MMC upper and lower arm currents, $V_{d c}$ is the dc link voltage, $v_{1}$ and $v_{2}$ are the voltages developed across the entire cell capacitors of the upper and lower arms, $v_{o}$ is the output phase voltage relative to the virtual supply mid-point, and $R_{a}$ and $L_{a}$ are the resistance and inductance of the arm reactors.

Subtracting (3) from (2), gives

$$
-v_{1}+v_{2}-2 v_{o}=R_{a}\left(i_{1}-i_{2}\right)+L_{a} \frac{d\left(i_{1}-i_{2}\right)}{d t}
$$

After combining (1) and (4):

$$
-v_{1}+v_{2}-2 v_{o}=R_{a} i_{o}+L_{a} \frac{d i_{o}}{d t}
$$

Equation (5) relates output phase current $i_{o}$ to inverter output voltage $v_{o}$ and upper and lower arm voltages $v_{l}$ and $v_{2}$. This equation shows that in order to synthesize a pure sinusoidal ac current $i_{o}$ at the output phase, the left side of (5) must be a pure sinusoid, this means $-v_{1}+v_{2}-2 v_{o}$ must be pure ac of sinusoidal form. Adding equation (2) to (3) yields: 


$$
V_{d c}-\left(v_{1}+v_{2}\right)=R_{a}\left(i_{1}+i_{2}\right)+L_{a} \frac{d}{d t}\left(i_{1}+i_{2}\right)
$$

If the left side of equation (6) is controlled to be pure DC, sum of the upper and lower arm currents $i_{1}+i_{2}$ must be DC, therefore:

$$
i_{1}+i_{2}=i_{d c}
$$

This means equation (6) can be re-arranged as:

$$
V_{d c}-\left(v_{1}+v_{2}\right)=R_{a} i_{d c}+L_{a} \frac{d i_{d c}}{d t}
$$

If $v_{1}+v_{2}$ is controlled to be higher than $V_{\mathrm{dc}}$, power flow will be from the ac side to the dc side; when lower than $V_{\mathrm{dc}}$ the power flow is in the opposite direction. Based on these assumptions, if $v_{1}+v_{2}$ is regulated at $V_{c}$ :

$$
v_{1}+v_{2}=V_{c}
$$

This equation permits the converter output voltage to be expressed as: $v_{o}=1 / 2 m V_{c}$ sin $\omega t$, whence, re-arranged:

$$
-v_{1}+v_{2}=m V_{c} \sin \omega t
$$

Where, $m$ is the modulation index.

After solving (9) and (10), the voltages across the upper and lower arms are:

$$
\begin{aligned}
& v_{1}=\frac{1}{2} V_{c}(1-m \sin \omega t) \\
& v_{2}=\frac{1}{2} V_{c}(1+m \sin \omega t)
\end{aligned}
$$

Equation (11) provides the mathematical proof of the complementary operation of FB-MMC arms. From (11), modulation waveforms for the upper and lower arms can be resolved into dc and ac components as:

$$
\begin{aligned}
& m_{1}=(1-m \sin \omega t)=m_{d}-m_{a} \\
& m_{2}=(1+m \sin \omega t)=m_{d}+m_{a}
\end{aligned}
$$

where $m_{d}=1$ and $m_{a}=m \sin \omega t$. Similarly, the upper and lower arm currents of the modular converter are resolved into difference and common mode components as:

$$
\begin{aligned}
& i_{1}=i_{d 1}+i_{o 1} \\
& i_{2}=i_{d 2}+i_{o 2}
\end{aligned}
$$

After substituting (13) into (1):

$$
\left(i_{d 1}-i_{d 2}\right)+\left(i_{o 1}-i_{o 2}\right)=i_{o}
$$

The dc component of equation (14) must vanish in order to synthesize sinusoidal output current $i_{o}$ : This means $i_{d 1}-i_{d 2}=0 \Rightarrow i_{d 1}=i_{d 2}=i_{d}$. Similarly, substitute (13) into (7):

$$
\left(i_{d 1}+i_{d 2}\right)+\left(i_{o 1}+i_{o 2}\right)=i_{d c}
$$

For the common mode current in (15) to be pure DC current, as assumed, its ac fundamental component $i_{o 1}+i_{o 2}$ must vanish; therefore $i_{O I}=-i_{O 2}$. Substituting $i_{o l}=-i_{O 2}$, yields $i_{o l}=1 / 2 i_{O}$ and $i_{o 2}=-1 / 2 i_{o}$, showing:

$$
\begin{aligned}
& i_{1}=i_{d c}+\frac{1}{2} i_{o} \\
& i_{2}=i_{d c}-\frac{1}{2} i_{o}
\end{aligned}
$$

Equation (16) is the mathematical proof of the current distribution in the modular converter arms, which is universally accepted and widely used in the literature, but without any mathematical proof.

From (8) and (9), $i_{d c}$ can be written as:

$$
i_{d c}=K_{1} e^{-\frac{R_{a}}{L_{a}} t}+\frac{V_{d c}-V_{c}}{2 R_{a}}
$$

Substituting (10) into (5):

$$
i_{o} R_{a}+L_{a} \frac{d i_{o}}{d t}=-2 v_{o}+m V_{c} \sin \omega t
$$

Assuming the load consists of an inductor $L$ and a reactor $R$, then:

$$
v_{o}=i_{o} R+L \frac{d i_{o}}{d t}
$$

Substituting (19) into (18):

$$
2\left(R+\frac{1}{2} R_{a}\right) i_{o}+2\left(L+\frac{1}{2} L_{a}\right) \frac{d i_{o}}{d t}=m V_{c} \sin \omega t
$$

Considering $R_{T}=2\left(\frac{1}{2} R_{a}+R\right)$ and $L_{T}=2\left(\frac{1}{2} L_{a}+L\right)$, then (18) can be derived as:

$$
i_{o} R_{T}+L_{T} \frac{d i_{o}}{d t}=m V_{c} \sin \omega t
$$

From (21), $i_{o}$ can be written as:

$$
i_{o}=K e^{-R_{T} t / L_{T}}+\frac{\frac{1}{2} m V_{c}}{\sqrt{R_{T}^{2}+\left(\omega L_{T}\right)^{2}}} \sin (\omega t+\varphi)
$$

Where, $\varphi=\tan ^{-1} \frac{\omega L_{T}}{R_{T}}$.

From equation (22), the steady state load current $i_{o}$ is determined by $V_{c}$, combined resistances and inductances of the load and arm reactors, and modulation index. The decay of the transient component of $i_{o}$ is determined by the combined time constant $\tau_{c}=L_{T} / R_{T}$.

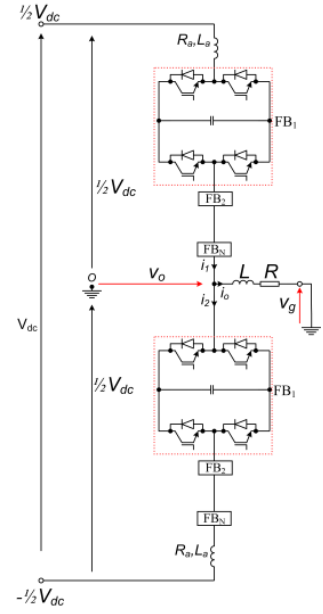

(a)

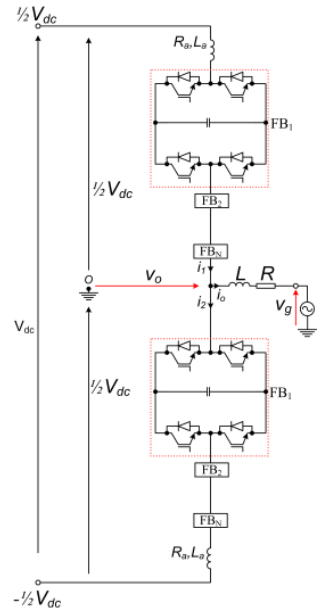

(b)

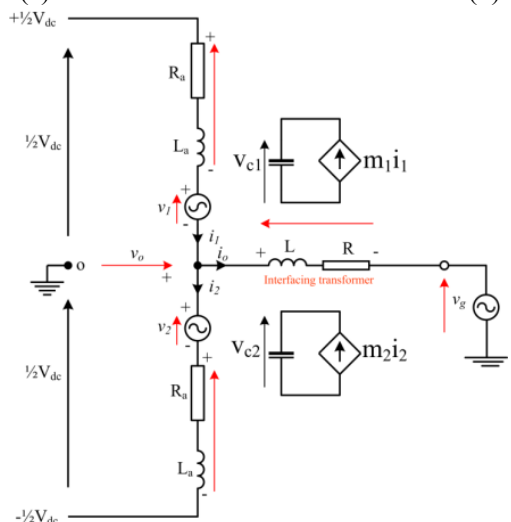

(c)

Figure 1: Single-phase of FB-MMC (a) connected to passive load, (b) connected to grid and (c) linear model connected to grid(where $m_{1}$ and $m_{2}$ are upper and lower arm modulation functions; $V_{c l}$ and $V_{c 2}$ are voltage of the equivalent cell capacitors of the upper and lower arms) 


\section{Control OF FUll-BRIdGe Modular MUltileVel CONVERTER}

FB-MMC in Figure 1 can be controlled using complimentary modulation functions illustrated by equations (11) and (12) However, control scheme in Figure 2 varies both components of the modulations functions $m_{a}$ and $m_{d}$ widely to extend control range of FB-MMC beyond that can be achieved with most of the existing control strategies. To operate FB-MMC with positive and negative dc link voltage, $m_{a}$ and $m_{d}$ must be allowed to vary over full control range: $-1 \leq m_{a} \leq 1$ and $1 \leq m_{d} \leq 1$. In normal operation, $m_{d}$ is regulated around 1(buck mode), and in this mode, FB-MMC generates its output voltage $\left(v_{o}\right)$ by inserting cell capacitors of both arms in opposite polarities to that of the dc link voltage (only subtractive states are utilized). However, cell capacitor insertion with the same polarity as the dc link (additive states) is allowed only during the intermediate voltage levels to accelerate cell capacitor voltage balancing. Any reduction in dc link voltage $\left(V_{d c}\right)$ will be associated by reduction in $m_{d}$, where $m_{d} \approx V_{d c} / V_{c}$ and $V_{c}$ is the sum of the cell capacitor voltages in each arm. When the dc link voltage is reduced until $m_{a}$ crosses to negative, the FB-MMC changes its operating mode to boost. In this mode, FB-MMC can insert some of the cell capacitors with the same polarity as that of the dc link voltage (additive states); and the cell capacitors in each arm are used as virtual dc links, provided the sum of the cell capacitor voltages of each arm is maintained around $V_{d c}$. For practical considerations related to the VSC dc cable insulation, the usable range of $m_{d}$ is limited to $0 \leq m_{d} \leq 1$. However, $-1 \leq m_{d} \leq 0$ represents a new operating region, which is a mirror of that when $0 \leq m_{d} \leq 1$. In this mode, the MMC can operate normally with the dc link voltage polarity reversed, with voltage stresses across the cell capacitors and switching devices are fully controlled. This mode permits the additive switch states to be used in conjunction with subtractive states at the intermediate voltage levels to accelerate cell capacitor voltage balancing.

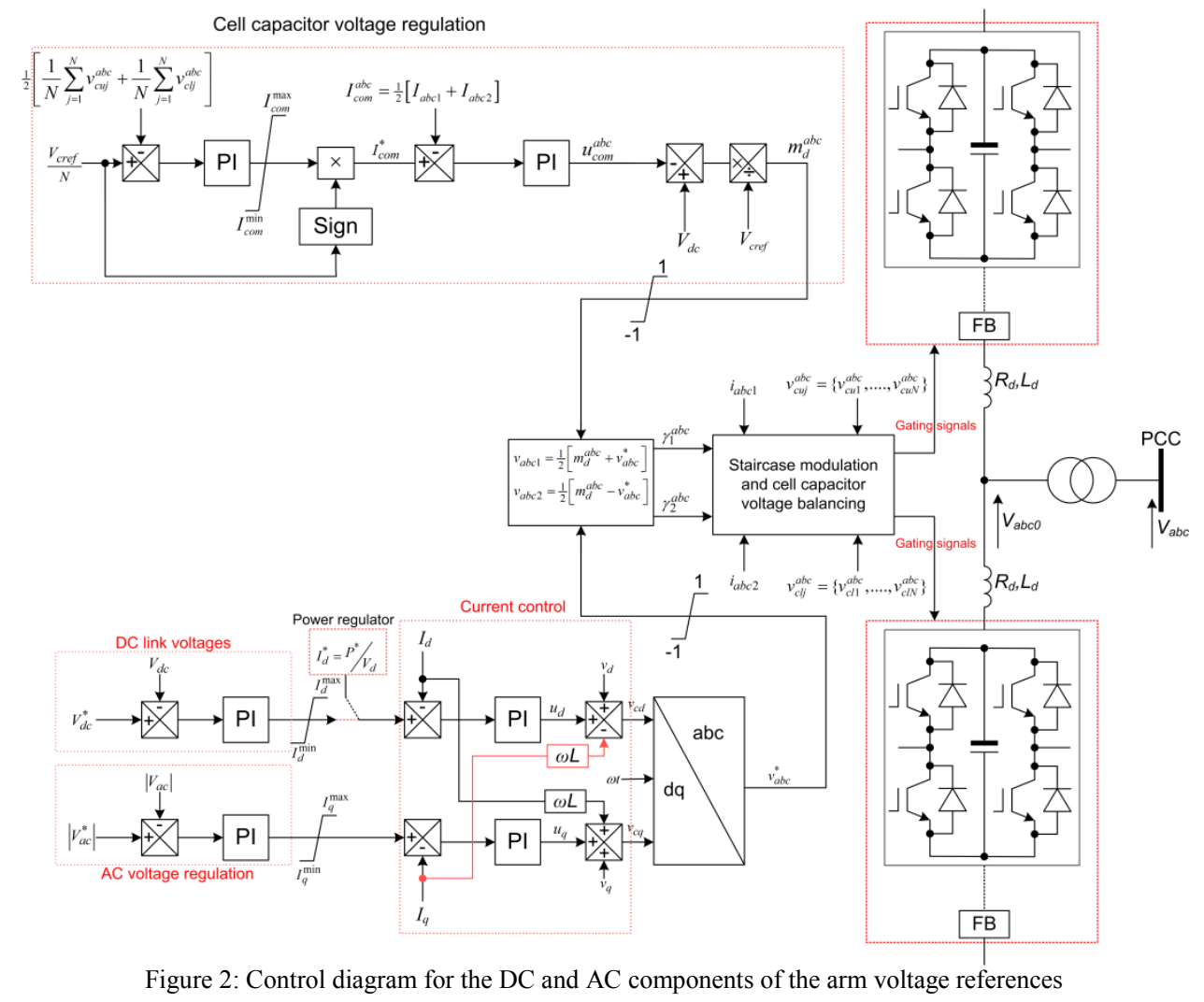

\section{Simulations}

To demonstrate the extended control range FB-MMC can offer when control scheme in Figure 2 is used, a two-terminal HVDC link that employs FB-MMC with 21 cells per arm is simulated, with parameters listed in Table 1. Converter terminals $\mathrm{VSC}_{1}$ and $\mathrm{VSC}_{2}$ are designated to control active power and dc voltage level respectively; both with unity power factors at their point of common couplings. Initially, $\mathrm{VSC}_{1}$ is commanded to import $800 \mathrm{MW}$ from $\mathrm{G}_{2}$ to $\mathrm{G}_{1}$, at $t=0.4 \mathrm{~s}$, it power output is reduced to $400 \mathrm{MW}$ and restored to $800 \mathrm{MW}$ at $t=2 \mathrm{~s}$. Whilst $\mathrm{VSC}_{2}$ is initially commanded to maintain dc link voltage at $640 \mathrm{kV}$; at $t=0.5 \mathrm{~s}$ its $\mathrm{dc}$ link voltage is reduced to $320 \mathrm{kV}$, and then restored to $640 \mathrm{kV}$ at $t=1.6 \mathrm{~s}$. At $t=2.5 \mathrm{~s}$, the cell capacitor voltages of $\mathrm{VSC}_{2}$ are increased by $10 \%$ to demonstrate the ability of the presented control scheme in regulating the cell capacitor voltages independent of the dc link voltage. Results obtained from this test are displayed in Figure 3. Observe that the ac currents $\mathrm{VSC}_{1}$ and $\mathrm{VSC}_{2}$ exchange with $\mathrm{G}_{1}$ and $\mathrm{G}_{2}$ and their arm currents in Figure 3 (a) and (b), and (c) and (d) are well regulated, including during period when dc link voltage is reduced by $50 \%$ of its rated. Figure 3 (e) and (f) show the dc link current and voltage, both measured at the terminal of the $\mathrm{VSC}_{2}$. Notice that $\mathrm{VSC}_{2}$ is acting as power balancer as the 
energy levels of the cell capacitors and dc line distributed capacitors change with the dc link voltage or cell capacitor voltage (draws the deficit from the ac grid or returns the surplus to the ac grid). Figure $3(\mathrm{~g})$ and $(\mathrm{h})$ show that although the dc voltage is varied from $640 \mathrm{kV}$ to $320 \mathrm{kV}$ and vice versa, the cell capacitor voltages of $\mathrm{VSC}_{1}$ and $\mathrm{VSC}_{2}$ are maintained nearly constant at $V_{d c} / N$. The plot for the cell capacitor voltages of the $\mathrm{VSC}_{1}$ displayed in Figure 3 (h) confirms that the presented control strategy permits FBMMC cell capacitors to be regulated at any arbitrary setpoint, provided the sum of the cell capacitor voltages of each arm is greater than the peak of phase line-to-line voltage. Figure 3 (i) and (j) show snapshots of the voltage developed across upper and lower arms of $\mathrm{VSC}_{1}$, zoomed around transition of dc link voltage from $640 \mathrm{kV}$ to $320 \mathrm{kV}$ and when the dc link voltage is $320 \mathrm{kV}$. Observe that the dc components of the arm voltages (corresponding to $m_{d}$ ) vary with dc link voltage as previously illustrated. Notice that when dc link voltage is $320 \mathrm{kV}$, the voltages developed across the upper and lower arms cross to negative, and this will trigger the use of additive states as discussed in section III.

Table 1: system parameters

\begin{tabular}{|c|c|}
\hline Parameters & Value \\
\hline DC link voltage $\left(V_{d c}\right)$ & $\pm 320 \mathrm{kV}$ \\
\hline Converter terminals nominal power & 1000MVA \\
\hline Converter terminals rated active power & 950MW \\
\hline Nominal ac voltage & $300 \mathrm{kV}$ \\
\hline Inductance of the arm reactance $\left(L_{d}\right)$ & $15 \mathrm{mH}$ \\
\hline $\begin{array}{l}\text { Arm reactance plus switching device on-state } \\
\text { resistance }\left(R_{d}\right)\end{array}$ & $0.5 \Omega$ \\
\hline Interfacing transformer nominal power & 1000MVA \\
\hline Interfacing transformer voltage ratio & $300 \mathrm{kV} / 400 \mathrm{kV}$ \\
\hline Interfacing transformer per unit reactance & $0.2 \mathrm{pu}$ \\
\hline AC grid voltage $\left(\mathrm{G}_{1}\right.$ and $\left.\mathrm{G}_{2}\right)$ & $400 \mathrm{kV}$ \\
\hline AC grid three-phase short circuit level & 20000MVA \\
\hline $\mathrm{X} / \mathrm{R}$ & 15 \\
\hline DC cable resistance & $0.009 \Omega / \mathrm{km}$ \\
\hline DC cable inductance & $1.1 \mathrm{mH} / \mathrm{km}$ \\
\hline DC cable capacitance & $0.23 \mu \mathrm{Fkm}$ \\
\hline DC cable length & $100 \mathrm{~km}$ \\
\hline
\end{tabular}

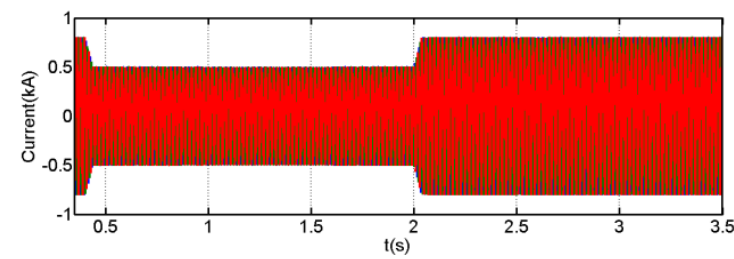

(a) Current waveforms $\mathrm{VSC}_{1}$ exchanges with $\mathrm{G}_{1}$

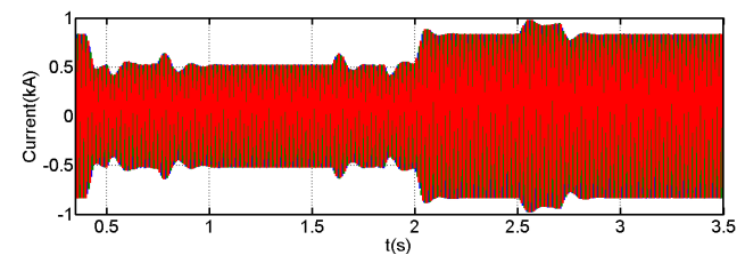

(b) Current waveforms $\mathrm{VSC}_{2}$ exchanges with $\mathrm{G}_{2}$

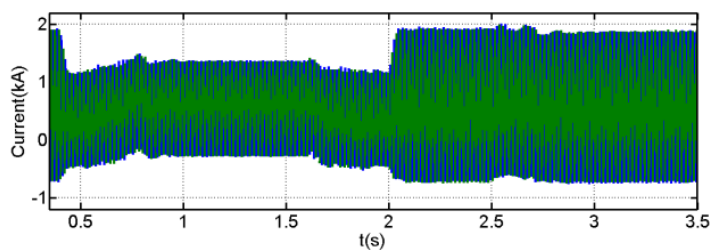

(c) $\mathrm{VSC}_{1}$ upper and lower arm currents (phase a)

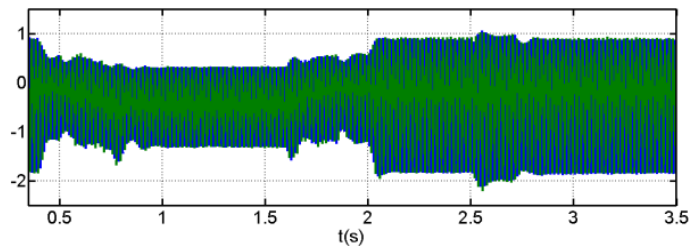

(d) $\mathrm{VSC}_{2}$ upper and lower arm currents (phase a)

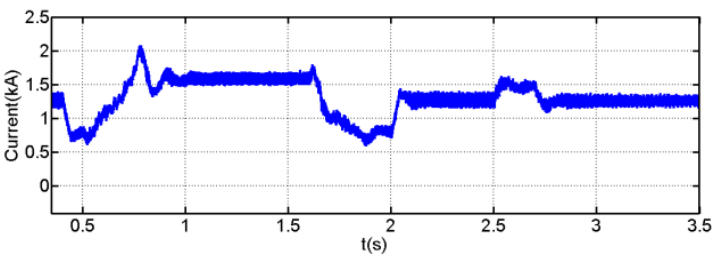

(e) DC link current

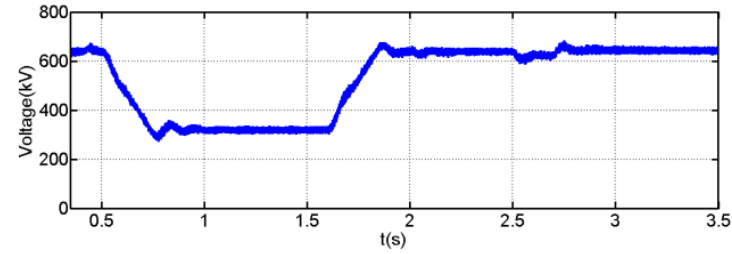

(f) $\mathrm{VSC}_{2} \mathrm{dc}$ link voltage

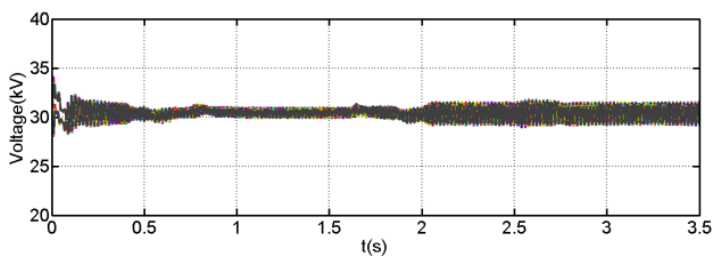

(g) $\mathrm{VSC}_{1}$ cell capacitor voltages

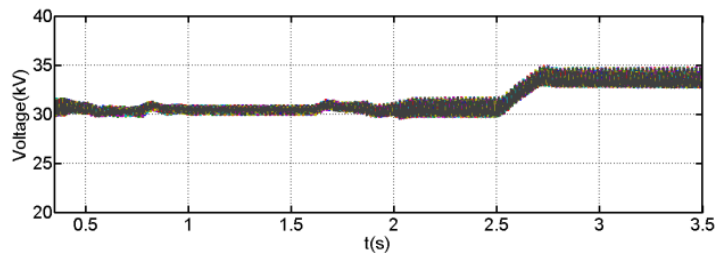

(h) $\mathrm{VSC}_{2}$ cell capacitor voltages

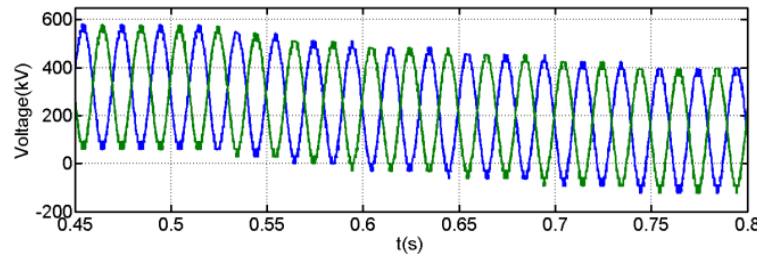

(i) Snapshot of the voltage waveforms developed across the upper and lower arms of the FB-MMC, zoomed around transition of dc link voltage from $640 \mathrm{kV}$ to $320 \mathrm{kV}$ 


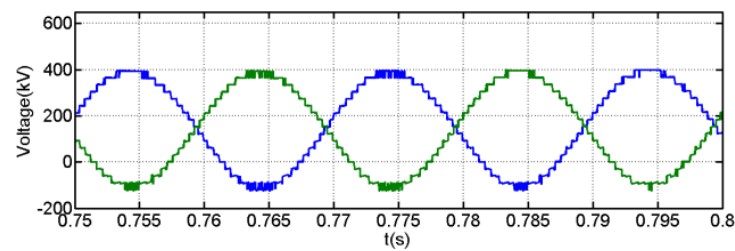

(j) Snapshot of the voltage waveforms developed across the upper and lower arms of the FB-MMC when dc link voltage is $320 \mathrm{kV}$

Figure 3: Selected waveforms that illustrating extended control range of the FB-MMC HVDC link, including decoupling of the cell capacitor voltage regulation from dc link voltage

\section{CONCLUSION}

This paper presented a control scheme that permits the cell capacitor voltages of the FB-MMC to be regulated independent of physical dc link. This feature allows FBMMC to exchange active and reactive powers with the ac grid, including when its dc link voltage is lower than the peak of the line-to-line voltage. The validity of the presented control scheme is confirmed using simulations performed on two-terminal HVDC link that employs 21-cell FB-MMC.

\section{REFERENCES}

[1] Y. Wan, S. Liu, and J. Jiang, "Generalised analytical methods and current-energy control design for modular multilevel cascade converter," Power Electronics, IET, vol. 6, pp. 495-504, 2013.

[2] G. Konstantinou, M. Ciobotaru, and V. Agelidis, "Selective harmonic elimination pulse-width modulation of modular multilevel converters," Power Electronics, IET, vol. 6, 2013.

[3] W. Can, H. Quanrui, and O. Boon-Teck, "Reduction of lowfrequency harmonics in modular multilevel converters (MMCs) by harmonic function analysis," Generation, Transmission \& Distribution, IET, vol. 8, pp. 328-338, 2014.

[4] H. Quanrui, L. Guo-Jie, and O. Boon-Teck, "Approximate model and low-order harmonic reduction for high-voltage direct current tap based on series single-phase modular multilevel converter," Generation, Transmission \& Distribution, IET, vol. 7, pp. 1046 1054, 2013.

[5] G. P. Adam;, K. H. Ahmed;, and B. W. Williams, "Mixed cells modular multilevel converter," presented at the IEEE International Symposium on Industrial Electronics (ISIE 2014), ISTANBUL, 2014

[6] M. A. Perez, S. Bernet, J. Rodriguez, S. Kouro, and R. Lizana, "Circuit Topologies, Modeling, Control Schemes, and Applications of Modular Multilevel Converters," Power Electronics, IEEE Transactions on, vol. 30, pp. 4-17, 2015.

[7] I. A. Gowaid, G. P. Adam, A. M. Massoud, S. Ahmed, D. Holliday, and B. W. Williams, "Quasi Two-Level Operation of Modular Multilevel Converter for Use in a High-Power DC Transformer with DC Fault Isolation Capability," Power Electronics, IEEE Transactions on, vol. PP, pp. 1-1, 2014. G. P. Adam, K. H. Ahmed, S. J. Finney, K. Bell, and B. W Williams, "New Breed of Network Fault-Tolerant VoltageSource-Converter HVDC Transmission System," Power Systems, IEEE Transactions on, vol. 28, pp. 335-346, 2013.

[9] M. M. C. Merlin, T. C. Green, P. D. Mitcheson, D. R. Trainer D. R. Critchleył, and R. W. Crookes $\dagger$, "A New Hybrid MultiLevel Voltage-Source Converter with DC Fault Blocking Capability," in IET ACDC2010, London,UK, 2010.

[10] D. Schmitt, Y. Wang, T. Weyh, and R. Marquardt, "DC-side fault current management in extended multiterminal-HVDC-grids," in Systems, Signals and Devices (SSD), 2012 9th International Multi-Conference on, 2012, pp. 1-5.

[11] R. Marquardt, "Modular Multilevel Converter topologies with DC-Short circuit current limitation," in Power Electronics and ECCE Asia (ICPE \& ECCE), 2011 IEEE 8th International Conference on, 2011, pp. 1425-1431.
[12] R. Marquardt, "Modular Multilevel Converter: An universal concept for HVDC-Networks and extended DC-Busapplications," in Power Electronics Conference (IPEC), 2010 International, 2010, pp. 502-507.

[13] S. Allebrod, R. Hamerski, and R. Marquardt, "New transformerless, scalable Modular Multilevel Converters for HVDC-transmission," in Power Electronics Specialists Conference, 2008. PESC 2008. IEEE, 2008, pp. 174-179.

[14] M. Glinka and R. Marquardt, "A new AC/AC multileve converter family," Industrial Electronics, IEEE Transactions on, vol. 52, pp. 662-669, 2005.

[15] A. Lesnicar and R. Marquardt, "An innovative modular multilevel converter topology suitable for a wide power range," in Power Tech Conference Proceedings, 2003 IEEE Bologna, 2003, p. 6 pp. Vol.3.

[16] M. Hagiwara, R. Maeda, and H. Akagi, "Control and Analysis of the Modular Multilevel Cascade Converter Based on Double-Star Chopper-Cells (MMCC-DSCC)," Power Electronics, IEEE Transactions on, vol. PP, pp. 1-1,2010.

[17] H. Akagi, "Classification, terminology, and application of the modular multilevel cascade converter (MMCC)," in Power Electronics Conference (IPEC), 2010 International, 2010, pp. 508-515.

[18] H. Akagi and R. Kitada, "Control of a modular multilevel cascade BTB system using bidirectional isolated DC/DC converters," in Energy Conversion Congress and Exposition (ECCE), 2010 IEEE, 2010, pp. 3549-3555.

[19] M. Hagiwara and H. Akagi, "Control and Experiment of Pulsewidth-Modulated Modular Multilevel Converters," Power Electronics, IEEE Transactions on, vol. 24, pp. 1737-1746, 2009.

[20] A. Nami, L. Wang, and F. Dijkhuizen, "Five level cross connected cell for cascaded converters," presented at the European Power Electronics (EPE2013), Lille, France, 2013.

[21] C. Govindaraju and K. Baskaran, "Efficient Sequential Switching Hybrid-Modulation Techniques for Cascaded Multilevel Inverters," Power Electronics, IEEE Transactions on, vol. 26, pp. $1639-1648,2011$

[22] N. Sujitha and K. Ramani, "A new Hybrid Cascaded H-Bridge Multilevel inverter - Performance analysis," in Advances in Engineering, Science and Management (ICAESM), 2012 International Conference on, 2012, pp. 46-50.

[23] S. Laali, K. Abbaszade, and H. Lesani, "New hybrid control methods based on multi-carrier PWM techniques and charge balance control methods for cascaded multilevel converters," in Electrical and Computer Engineering (CCECE), 2011 24th Canadian Conference on, 2011, pp. 000243-000246.

[24] M. P. Bahrman and B. K. Johnson, "The ABCs of HVDC transmission technologies," Power and Energy Magazine, IEEE, vol. 5, pp. 32-44, 2007.

[25] H. P. Mohammadi and M. T. Bina, "A Transformerless MediumVoltage STATCOM Topology Based on Extended Modular Multilevel Converters," Power Electronics, IEEE Transactions on, vol. 26, pp. 1534-1545, 2011.

[26] D. C. Ludois and G. Venkataramanan, "Simplified Terminal Behavioral Model for a Modular Multilevel Converter," Power Electronics, IEEE Transactions on, vol. 29, pp. 1622-1631, 2014.

[27] D. Fujin and C. Zhe, "A Control Method for Voltage Balancing in Modular Multilevel Converters," Power Electronics, IEEE Transactions on, vol. 29, pp. 66-76, 2014.

[28] S. Qiang, L. Wenhua, L. Xiaoqian, R. Hong, X. Shukai, and L. Licheng, "A Steady-State Analysis Method for a Modular Multilevel Converter," Power Electronics, IEEE Transactions on, vol. 28, pp. 3702-3713, 2013.

[29] J. Ebrahimi, E. Babaei, and G. B. Gharehpetian, "A New Topology of Cascaded Multilevel Converters With Reduced Number of Components for High-Voltage Applications," Power Electronics, IEEE Transactions on, vol. 26, pp. 3109-3118, 2011.

[30] M. Rashed, C. Klumpner, and G. Asher, "Repetitive and Resonant Control for a Single-Phase Grid-Connected Hybrid Cascaded Multilevel Converter," Power Electronics, IEEE Transactions on, vol. 28, pp. 2224-2234, 2013.

[31] K. Ilves, A. Antonopoulos, S. Norrga, and H. P. Nee, "SteadyState Analysis of Interaction Between Harmonic Components of Arm and Line Quantities of Modular Multilevel Converters," 
Power Electronics, IEEE Transactions on, vol. 27, pp. 57-68, 2012.

[32] G. Adam and I. Davidson, "Robust and Generic Control of FullBridge Modular Multilevel Converter High-Voltage DC Transmission Systems," Power Delivery, IEEE Transactions on, vol. PP, pp. 1-1, 2015. 